\title{
THE IMPACT OF BANKING NETWORK SERVICES THROUGH PROFITABILITY ON INDONESIA BANKING COMPANIES
}

\author{
Euphrasia Susy SUHENDRA1, Dr., Ir.MS, Gunadarma University, Indonesia \\ Emmy INDRAYANI'2, SE. MMSI, Gunadarma University, Indonesia \\ Dia RAGASARI ${ }^{3}$, SKom., MM, Gunadarma University, Indonesia \\ Gesty ERNESTIVITA4, S.S., MM, Nusantara PGRI University, Indonesia
}

DOI: https://doi.org/10.36004/nier.es.2020.2-01

JEL Classification: E59, G21, M21, 033

UDC: 336.71(594)

\section{ABSTRACT}

The banking sector has embraced the use of technology to serve its clients faster and also to do more with less. Emerging technologies have changed the banking industry from paper and branch based banks to digitized and networked banking services. ATM machines and the number of switching networks is among the technologies used in the banking industry. The aim of this study is to analyze the influence of network switching and number of ATM machine through non-interest income to profitability. The paper proposes to examine whether the number of ATM machines of the bank affect the fee-based income, whether the amount of ATM switching network membership of the bank affects the bank's fee-based income, and whether the feebased income affects the performance of the bank. The study was conducted in banking companies belonging to members of the switching principal network appointed by Bank Indonesia and switching network companies in Indonesia. The data used for this research is represented by financial statements from Indonesian commercial banks that have gone public, data from banking magazines and data available from each bank's page avaiolable for open access. The number of samples from this study is represented by 30 commercial banks that are listed in IDX. The results of this study show that the number of ATM machines has no significant effect on Fee Based Income. At the same time, the number of switching networks has a significant effect toward Fee Based Income, and the Fee Based Income has no significant effect on the bank's return on investment.

Keywords: ATM, switching network, fee based income, profitability.

Sectorul bancar a acceptat utilizarea tehnologiei pentru a servi clienții săi mai repede și, de asemenea, pentru a face mai multe acțiuni cu mai puține resurse. Tehnologiile emergente au schimbat industria bancară de la bănci cu lucru pe hârtie și sucursale bancare, la servicii bancare digitalizate și în rețea. Bancomatele și numărul de rețele de comutare reprezintă una dintre tehnologiile utilizate în industria bancară. Scopul acestui studiu este de a analiza influența comutării rețelei și numărul de bancomate prin venituri fără dobândă până la profitabilitate. Lucrarea își propune să examineze dacă numărul de bancomate ale băncii afectează venitul pe bază de comisioane, dacă valoarea calității de membru al rețelei de comutare bancară afectează venitul pe bază de comisioane al băncii și dacă venitul pe bază de comisioane afectează performanța băncii. Studiul a fost realizat pe companii bancare aparținând membrilor rețelei principale de comutare numite de Bank Indonesia și companiilor de rețele de comutare din Indonezia. Datele utilizate pentru această cercetare sunt reprezentate de situațiile financiare ale băncilor comerciale indoneziene care au devenit publice, datele din revistele bancare și datele disponibile de pe pagina fiecărei bănci în acces deschis. Eșantionarea acestui studiu este reprezentată de 30 de bănci comerciale care sunt listate în IDX. Rezultatele acestui studiu arată că numărul de bancomate nu are niciun efect semnificativ asupra veniturilor bazate pe taxe. În același

\footnotetext{
${ }^{1}$ ID ORCID 0000-0002-3864-136X $₫ e$-mail: susys@staff.gunadarma.ac.id

2 ID ORCID 0000-0002-8720-1352 e-mail:emmyindra@gmail.com

3 ID ORCID 0000-0003-4014-0393 e-mail: diaragasari4@gmail.com

${ }^{4}$ ID ORCID 0000-0002-3864-1045 e-mail: gesty@unpkediri.ac.id
}

December No. 2/2020 
timp, numărul de rețele de comutare are un efect semnificativ asupra veniturilor bazate pe taxe, iar Veniturile bazate pe taxe nu au un efect semnificativ asupra rentabilitătii investiției bancare.

Cuvinte-cheie: bancomat, rețea de comutare, venituri bazate pe taxe, profitabilitate.

Банковский сектор стал использовать технологии, чтобы быстрее обслуживать клиентов, а также делать больше с меньшими затратами. Новые технологии изменили банковскую отрасль от банков, основанных на бумажном документообороте и филиалах, до банков с цифровыми и сетевыми услугами. Банкоматы и количество коммутационных сетей являются одной из технологий, используемых в банковской сфере. Целью данного исследования является анализ влияния коммутации сети и количества банкоматов через непроцентный доход на прибыльность. В статье предлагается изучить, влияет ли количество банкоматов банка на комиссионный доход, влияет ли сумма участия банка в коммутационной сети банкоматов на комиссионный доход банка и влияет ли комиссионный доход на результаты деятельности банка. Исследование проводилось в банковских компаниях, принадлежащих членам основной коммутационной сети, назначенной Банком Индонезии, и коммутационных сетевых компаниях Индонезии. Данные, использованные для данного исследования, представлены финансовыми отчетами индонезийских коммерческих банков, которые стали общедоступными, данными из банковских журналов и данными, доступными на странищах каждого банка в открытом доступе. Выборка исследования представлена 30 коммерческими банками, которые перечислены в IDX. Результаты исследования показывают, что количество банкоматов не оказывает значительного влияния на комиссионный доход. В то же время, количество коммутируемых сетей оказывает существенное влияние на комиссионный доход, а комиссионный доход не оказывает значительного влияния на рентабельность инвестиций банка.

Ключевые слова: банкоматы, коммутационная сеть, комиссионный доход, прибыльность.

\section{INTRODUCTION}

Indonesia is a hugely significant market for financial services, not only in south-east Asia, but on the global stage, too. Home to more than 261 million people, it is the world's fourth most populous country and also the largest island nation on the planet, comprising more than 13,000 islands. From a financial services perspective, Indonesia has huge potential, but also some very real challenges to overcome, most notably financial inclusion. As the national government pursues initiatives to address this problem over the coming years, ATM deployment could prove a vital part of the mission.

Indonesia is the largest ATM market in south-east Asia, with the number of machines spread across the country passing the 100,000 mark in 2018, according to Retail Banking Research (RBR). It is a heavily cash-based society, meaning there is ongoing demand for ATM services. This is particularly relevant in light of the fact that, even though there are more than 35,000 bank branches in Indonesia and financial institutions (FIs) are expanding their physical networks into underserved areas, an increasing number of services are moving into digital channels. As a result, banks are seeking to maximize efficiency in their branches through strategies such as self-service automation. From a financial inclusion perspective, innovation in the ATM channel could have an important part to play in expanding service availability throughout the country. The development of the 'bank in a box' concept means it's now possible for banks to use ATMs to provide a range of services in areas where it might be impractical or financially infeasible to open a branch.

In the emergence of using ATMs, an ATM network company or a so-called switching company that will handle the connection and needs required in the implementation of using card as a payment instrument will also automatically appear. The company is working with banks in Indonesia. So far, an ATM interconnection company is mainly (fundamentally) hereinafter referred to in Indonesia as the switching company. The research features 3 switching companies that have operated and already hold a licence from Bank Indonesia PT. Artajasa Pembayaran Elektronis which manages the ATM Bersama network, PT. Rintis Sejahtera which manages the Prima ATM network, and PT. Daya Network Lest which manages the Alto ATM network. But in 2017 a new principal switching was present company which is also PT. It is the Telkomsigma or Himbara - ATM Link, which has operated an ATM network of stateowned banks, namely Bank BRI, Bank Mandiri, BNI and Ban BTN for approximately seven years. Himbara

December No. 2/2020 
Link was formed in order to realize the plan of Bank Indonesia to develop interconnection and interoperability of payment systems in Indonesia. In accordance with the Press Release of Bank Indonesia on 2018, a press release on "Developing Interconnection and Interoperability of Payment System with the National Payment Gateway (NPG)" while at the same time signing a Memorandum of Understanding conducted by four banks and three national principal switching companies (Bank Indonesia, 2016).

This research generally aimed at analyzing the effect of Bank Indonesia regulation on NPG creation on bank earnings and performance. In this study, NPG represented many network switchings owned by a bank. The study was conducted in banking companies belonging to members of the switching principal network appointed by Bank Indonesia and switching network companies in Indonesia. In detail the problems to be studied in this research were to first examine whether the number of ATM machines of the bank affect the fee-based income, secondly whether the amount of ATM switching network membership of the bank affects the bank's fee-based income, and the third whether the fee-based income affects the performance of the bank. The hypothesis of this study is three-fold. First, the number of ATM machines affect the bank's feebased income. Second, the amount of switching network membership used affects the bank's fee-based income. Third, the bank's fee-based income affects the performance of the bank.

\section{LITERATURE REVIEW}

The Bank is a financial intermediary institution generally established with the authority to accept deposits of money, lend money, and issue promissory notes or banknotes (Hoggson, 1926). In their development, banks need information technology. Information Systems Technology proves that it continuously plays an important role in building an organization and its existence. Therefore, it is necessary to align the strategic model between business strategy and information system/technology strategy to ultimately improve organizational performance. Alignment of strategies for companies to achieve targets supported by information systems in their business processes will provide accurate information for management (Hamzah, 2007).

The plastic card is basically a card issued by a particular bank or company and that can be used as a means of payment for the transaction of goods or services, guaranteeing the validity of checks issued, and for withdrawing cash (Siamat, 2005). The use of the term „credit card” actually causes confusion because the term is often meant also for other types of cards that are not always related to credit card functions. Therefore, the specific term used is a plastic card (plastic card) (Siamat, 2005).

All transactions conducted and using information technology in banking will require a special information technology for banking called Core Banking. Core Banking is the heart of a Bank. Core banking stores data of customers and their accounts and all transactions since the customer opened an account at the bank until it closes (www.teknologibank.com 2016). Core Banking is generally associated with retail banking. The main core banking function is to serve customers for funding, lending and deposit money. Another function of core banking is recording all transactions that occur in the customer's account either in the form of savings, loans, or payment transactions. Access to core banking can be done through many channels such as Teller (Branch), ATM, Internet Banking, Mobile Banking and others (www.teknologibank.com, 2016).

In addition to core banking, a vital technological element owned by the bank is ATM Switching. The ATM Switching solution is known by different names. Although in the international world this solution is called EFT Switching (Electronic Fund Transfer Switch), in Indonesia it is better known as ATM Switching. This naming is actually not appropriate because this solution is also used to drive POS/EDC (Electronic Data Capture). It is worth noting that the term ATM Switching refers to software used to drive physical channels (such as ATM and EDC), perform authorization and transaction routing, and electronic data exchange. ATM Switch solutions are used to serve as a link between the bank's physical channels (such as branch, POS/EDC, ATM, Internet Banking and Mobile Banking) with the Core Banking system. The solution also handles connections to third parties such as Local National Switch (Artajasa/ATM Bersama, ALTO, Link, Rintis/Prima), International Switch (Visa, MasterCard, Amex), Payment Provider (PLN, Telkom, Airline) (www.teknologibank.com, 2016).

\section{RESULTS OF OWN RESEARCH AND DISCUSSIONS}

Fee Based Income. Fee based income is the income obtained from transactions provided in other bank services (Kasmir, 2012). This definition explains that apart from collecting and distributing funds, banks also carry out other supporting service activities. These support services are provided to facilitate 
activities to collect and distribute funds that generate fee based income from the proceeds of providing bank services. Fee based income is the income other than operating income that is not shared with other parties. Some examples of banking services that generate fee-based income are transfers, collections, letters of credit, safe deposit boxes, credit cards, payment points for deposit accounts, bank guarantees, foreign exchange trading, commercial paper and traveler's checks.

Return On Asset (ROA). According to Fahmi (2013) ROA is one of the four ratios which measures the company's performance in terms of profitability. ROA measures the extent to which the company's ability to generate profits from assets used in the company. ROA is used as a measure of management effectiveness in managing its investment. ROA can be calculated by dividing earning after tax by total assets.

Network Switching and the number of ATMs are bank assets that play a role in the company's main operations. Automated Teller Machines contribute to the banking sector's effectiveness. The tremendous growth and development of technological advancement has been the driving force of the market Jagede, 2014). Another study regarding the relationship between electronic banking and bank performance is the one conducted by Margaretha (2015), which examines the differences in the performance of banks that use electronic banking and banks that do not use electronic banking. In fact, the result shows that banks that use electronic banking have a higher Return on Assets. In relation to this research, those instruments which can be classified as pertaining to electronic banking are internet banking, mobile banking, phone banking, EDC, ATM, SMS banking, videobanking (Abadi, 2015).

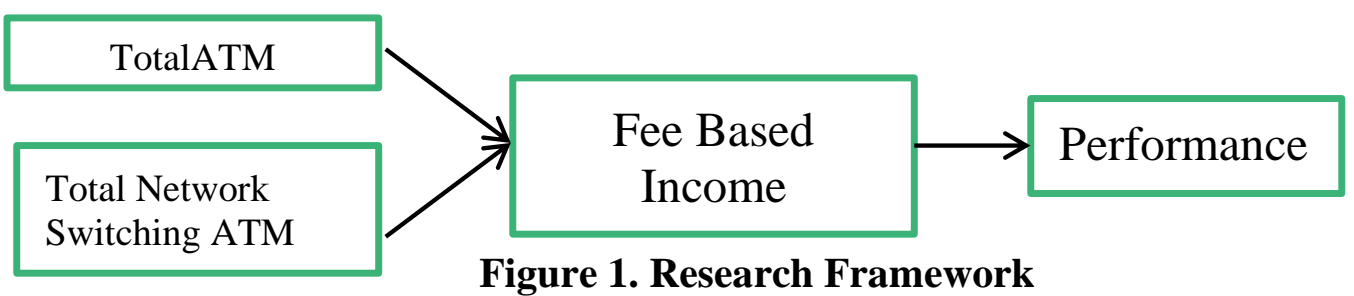

Source: Developed by the authors.

\section{Research Method \\ Research Variable}

Based on the issues to be discussed, then the specified variables are as follows:

Table 1

\section{Definition of Operational Variables}

\begin{tabular}{|c|c|c|}
\hline $\begin{array}{l}\text { Variable } \\
\text { name }\end{array}$ & $\begin{array}{l}\text { Variable } \\
\text { type }\end{array}$ & Definition \\
\hline $\operatorname{ATM}\left(\mathrm{X}_{1}\right)$ & $\begin{array}{l}\text { Independen } \\
\text { Variable }\end{array}$ & $\begin{array}{l}\text { The "atm" variable is the number of atm machines used by each company. The "atm" } \\
\text { variable is measured in equipment (machine) unis. Source obtained from Infobank } \\
\text { magazine January } 2019 \text { edition. }\end{array}$ \\
\hline $\begin{array}{l}\text { Netwok } \\
\text { Switching } \\
\left(\mathrm{X}_{2}\right)\end{array}$ & $\begin{array}{l}\text { Independen } \\
\text { Variable }\end{array}$ & $\begin{array}{l}\text { The variable "switching" is the number of bank switching networks, which banks use } \\
\text { to perform bank operational activities through electronic means. The variable } \\
\text { "switching" is measured in membership count. Source: obtained from Infobank } \\
\text { magazine January } 2019 \text { and website every bank. }\end{array}$ \\
\hline $\begin{array}{l}\text { Non Interest } \\
\left(\mathrm{Y}_{1}\right)\end{array}$ & $\begin{array}{l}\text { Dependen } \\
\text { Variable }\end{array}$ & $\begin{array}{l}\text { The "non-interest" variable is the nominal value with the rupiah unit representing the } \\
\text { amount of the bank's income earned from non-interest income, including the fee from } \\
\text { the transaction for using the ATM. Sources are obtained from the bank's quarterly } \\
\text { financial statements as of December } 2018 \text { from } 30 \text { selected banks. }\end{array}$ \\
\hline $\begin{array}{l}\text { Profitability } \\
\left(\mathrm{Y}_{2}\right)\end{array}$ & $\begin{array}{l}\text { Dependen } \\
\text { Variable }\end{array}$ & $\begin{array}{l}\text { The variable "ROA" represents the Return of Asset ratio that describes the ability of } \\
\text { the banking company in generating return on the management of the company's } \\
\text { assets. Data from this ratio is derived from the quarterly financial statements of banks } \\
\text { as of December } 2018 \text { from } 30 \text { selected banks, the unit of "ROA" variables used in this } \\
\text { provider is expressed in percentage, which is calculated manually. The reason for } \\
\text { choosing ROA ratio to represent bank performance is because of the profitability } \\
\text { ratios used to measure the effectiveness of a company in generating profits by using } \\
\text { its total assets. And ATM machines and switching networks are included in fixed } \\
\text { assets and bank inventories. }\end{array}$ \\
\hline
\end{tabular}

Source: Developed by the authors based. 


\section{Data Sample}

The data used in this research is from the financial statements, publications of banking companies and from magazines. The method of data retrieval is by downloading quarterly financial reports per December 2018 from each bank that becomes the object, and retrieving data that has been published in the January 2019 infobank magazine (Infobank, 2019). The banking company has an ATM machine over 200 units of machinery that is still operating and can be used by all customers. This research uses 30 banking companies as sample.

\section{Data and Analysis}

\section{Structural Model Test}

Based on the normality evaluation shows that the data is feasible to be used in the structural model feasibility test on the influence of network switching and ATM through fee based income to profitability which the result of structural model test is shown in Table 2 as below:

Table 2

Structural model test

\begin{tabular}{|l|c|c|c|}
\hline \multicolumn{1}{|c|}{ Good of Fit (GOF) Index } & Cut-off Value & Model & Good Fit \\
\hline Chi-square $\left(x^{2}\right)$ & & 0,157 & good fit \\
\hline Df $($ Degree Freedom) & Positive & 2 & good fit \\
\hline$P$ (probabilitas) & $>0,05$ & 0,924 & good fit \\
\hline RMSEA & 0 & 0,000 & good fit \\
\hline GFI & $>0,9$ & 0,997 & good fit \\
\hline
\end{tabular}

Source: Developed by the authors.

From the overall calculation on the measurement Overall Model Fit and Good of Fit, it can be concluded that the model study made on the whole has qualified measuring and Fit.

After testing the structural model, the next test is the SEM (Structural Equation Modeling) testing. Here are the results and output Path Diagram of the Standardized Estimates section of the research model.

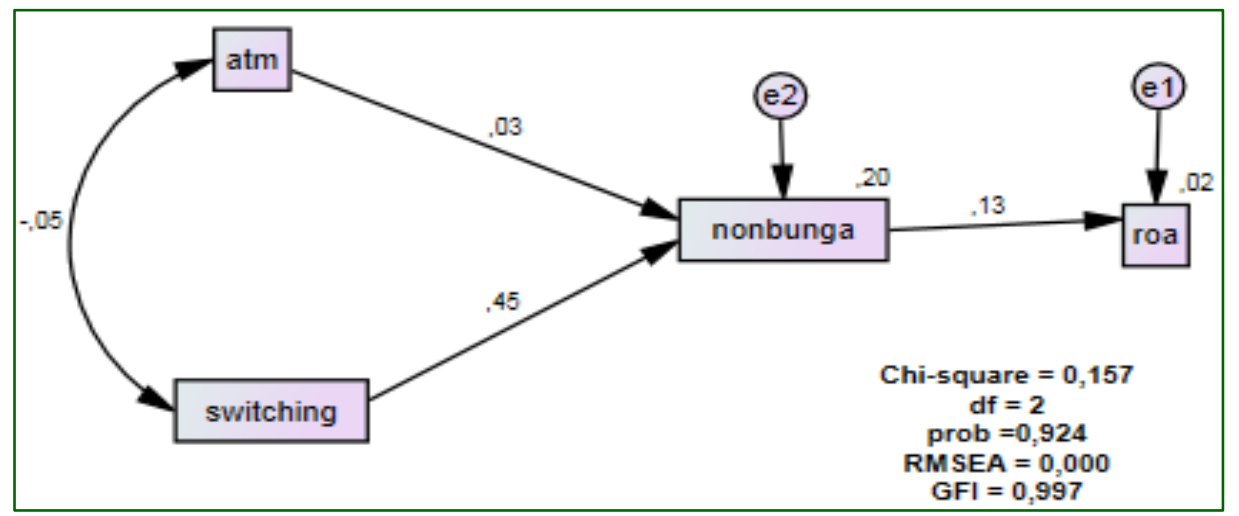

Source: Developed by the authors.

Figure 2. Path Diagram Output

Then, after testing Data Normality and Good of Fit, the next test is Structural Model Test. It's to test the relationship between constructs. The test is aims to see a significant and close relationship between independent and dependent variables. Here is the result.

Table 2

Result of Hypothesis Test

\begin{tabular}{|l|l|c|c|c|}
\hline \multicolumn{1}{|c|}{ Hypothesis } & \multicolumn{1}{|c|}{ Path } & P & Result of Probability & Estimate \\
\hline H1 & atm $\rightarrow$ fee based & 0,867 & Rejected & 0,028 \\
\hline H2 & switching $\rightarrow$ fee based & 0,006 & Accepted & 0,453 \\
\hline H3 & fee based $\rightarrow$ roa & 0,477 & Rejected & 0,131 \\
\hline
\end{tabular}

Source: Developed by the authors based. 
From the table above, it can be concluded that, the first hypothesis on the test results is the result that $\mathrm{H}_{1}$ hypothesis is rejected. Respectively, there is no relationship/influence between variable "atm" with variable "fee based", with probability is 0,867 above 0,05 and number of closeness 0,028 under 0,5 . And then the second hypothesis on the test results is that $\mathrm{H}_{2}$ is accepted. This means that there is a relationship between the "switching" variable and the "fee based" variable in which the probability is 0.006 below 0.05 and the closeness is 0.453 below 0.5 . and the last hypothesis, show $\mathrm{H}_{3}$ is also rejected. This means that there is no relationship between the "fee based" variable with the "ROA" variable in which the number of probability is 0.477 above 0.05 and the closeness is 0.131 below 0.5 .

According to the results of this test, it can be concluded that the number of ATM machines used by a bank to support bank operations to facilitate transactions done by customers does not guarantee an increase in bank non-interest income. The number of ATM machines does not contribute to an increase in non-interest income at banking companies. This can be due to the fact that there are many other means that can be used for transactions, for example EDC machines, Internet Banking, Mobile Banking, and others. Customers are thought to prefer banking transactions using online facilities rather than ATMs. This research is in line with the research of Jagede (2014) which states that although ATM is the driving force of fee-based income, it is the number of transactions that directly contributes to the amount of fee-based income.

\section{CONCLUSION AND RECOMMENDATIONS}

Based on test results and analysis results the conclusion of the research is, First, the number of ATM machines not affect to the bank's fee based income. Second, the amount of switching network membership used affects the bank's fee-based income. Then third, the bank's fee based income also does not affect to the performance of the bank. This research has answered the formulation of the problems that have been enunciated before. Further research can be directed to deep dive into the switching network factor, which is the aspect that shapes a bank's fee-based income, and also examines the size of a bank's assets which of course will affect the size of the switching network that it owns.

\section{REFERENCES}

1. ABADI, R. Mengenal Mobile Banking, Apa Keunggulan dan Kekurangannya? 2015, 25 desember [citat 10 august 2019]. Disponibil: https://www.cermati.com/artikel/mengenal-mobile-bankingapa-keunggulan-dan-kekurangannya

2. BANK INDONESIA. Siaran Pers: Kembangkan Interkoneksi dan Interoperabilitas Sistem Pembayaran dengan National Payment Gateway (NPG): siaran pers, 21 desember 2019. Jakarta, 2016 [citat 12 februarie 2017]. Disponibil: <http://www.bi.go.id/id/ruang-media/siaranpers/Pages/sp_1810516.aspx>

3. FAHMI, I. Analisis Laporan Keuangan. Cetakan ketiga. Bandung: Alfabeta, 2013.

4. HAMZAH, A. Penyelarasan Strategi Bisnis dan Strategi Sistem/Teknologi Informasi untuk Peningkatan Kinerja Organisasi. In: Proceeding Seminar Nasional Aplikasi Teknologi Informasi (SNATI 2007). Yogyakarta, 2007. pp 1-4. ISSN 1907-5022.

5. HOGGSON, N.F. Banking Through the Ages. New York: Dodd, Mead \& Company, 1926. 128 p.

6. INFOBANK. Data Jumlah ATM Bank di Indonesia. Jakarta, 2019, january.

7. JEGEDE, C.A. Effects of Automated Teller Machine on the Performance of Nigerian Banks. In: American Journal of Applied Mathematics and Statistics. 2014, vol. 2, no. 1, pp. 40-46. ISSN 23287306 [citat 27 martie 2020]. Disponibil: http://article.sciappliedmathematics.com/pdf/AJAMS-21-7.pdf DOI:10.12691/ajams-2 -1 -7.

8. KASMIR. Bank dan Lembaga Keuangan Lainnya. Jakarta: PT. Raja Grafindo Persada, 2012. ISBN 978-979-769-413-5.

9. FARAH, M. Dampak Electronic Bankingterhadap Kinerja Perbankan Indonesia. In: Jurnal Keuangan dan Perbankan. 2015, vol. 19, no. 3, september, pp. 514-524. ISSN 1410-8089.

10. SIAMAT, D. Manajemen Lembaga Keuangan: Kebijakan Moneter dn Perbankan. Edisi Kelima. Fakultas Ekonomi Universitas Indonesia. Jakarta, 2005. 750 p. ISBN 979-9242-0.

11. TEKNOLOGIBANK. Apa-itu-digital-banking. Jakarta, 2016, 13 may [citat 09 february 2020]. Disponibil: <http://teknologibank.com/detailpost/apa-itu-digital-banking>

\section{ARTICLE HISTORY}

Received 15 July 2020

Accepted 18 November 2020 